УАК: 378:811.11

ІГРОВІ ФОРМИ НА ЗАНЯТТЯХ 3 IHОЗЕМНОÏ МОВИ

ЯК ЗАСІБ ПІДВИЩЕННЯ МОТИВАЦІЇ СТУАЕНТІВ АО ВИВЧЕННЯ ЕКОНОМІЧНОГО ВОКАБУЛЯРІЮ ${ }^{\odot}$
Н.М. ТИМОЩУК, кандидат філологічних наук, доцент, доцент кафедри украӥнської та іноземнихмов, Вінницький національний аграрний університет (м. Вінниця)

У статті досліджено проблему підвищення мотиващії студентів немовних закладів вищої освіти до вивчення нової наукової (ділової) англійської лексики шляхом використання ігрових методів на заняттях з іноземної мови. Розглянуто мотивацію студентів закладу вищої освіти як необхідну складову навчального процесу. Представлено результати моніторингу щодо наявності проблеми засвоєння нової фахової лексики, оптимальної форми організачї навчання нових термінів $i$ найефективніших засобів навчання та їх запам'ятовування серед студентів факультету менеджменту та права Вінницького національного аграрного університету. Здійснено порівняльний аналіз якості та успішності студентів до та після використання ігрових форм на заняттях з дисиипліни "Іноземна мова професійного спрямування”. Зазначено, щуо опанування іншомовною фаховою лексикою - ключова складова у вивченні іноземної мови професійного спрямування, яка дає змогу підвищити ефективність навчального прочесу, сприяє формуванню компетентного фахівия, конкурентоспроможного у сучасних умовах. Доведено, щчо аналізована форма організачії засвоєння економічної фахової лексики значно покрашила здатність студентів ефективно запам'ятовувати нові англомовні фахові терміни, підвищила їх мотивацію до вивчення нової термінологічної лексики ділової англійської мови.

Ключові слова: мотивація, ігрова форма, терміни, лексика, іноземна мова професійного спрямування, професійна підготовка, когнітивний підхід, методика.

Рис.: 5. Літ.: 19.

\title{
GAMING FORMS AT FOREIGN LANGUAGE LESSONS AS A MEANS OF IMPROVING STUDENTS MOTIVATION TO STUDY ECONOMIC VOCABULARY
}

\section{TYMOSHCHUK Nataliia, Candidate of Philological Sciences, Associate Professor of the Ukrainian and Foreign Languages Department, Vinnytsia National Agrarian University (Vinnytsia)}

The article investigates the problem of increasing the motivation of students of nonlinguistic higher education institutions to study the new scientific (economic) English vocabulary through the use of game techniques in foreign language classes. The students'

${ }^{\odot}$ Н.М. ТИМОЩУК, 2019 


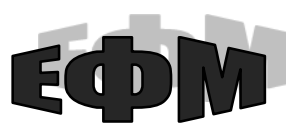

http://efm.vsau.org/

motivation of the higher education institution who studies a foreign language is a necessary component of the educational process. The results of monitoring on the existence of the problem of mastering the new professional vocabulary, the optimal form of new terms memorizing and the most effective means of teaching and memorizing vocabulary among students of the Faculty of Management and Law of Vinnytsia National Agrarian University are presented. A comparative analysis of the students' marks and successes before and after the game forms application at the classes of foreign professional language is conducted. It is noted that mastering foreign language professional vocabulary is a key component of a foreign professional language, it enables to increase the efficiency of the educational process, contributes to the formation of a competent specialist who is competitive in modern conditions. It is proved that the analyzed form of economic vocabulary teaching significantly improves the ability of students to memorize the new English-language professional terms effectively, increased their motivation to study the new terminology of the business English language.

Key words: motivation, game form, terms, vocabulary, foreign professional language, professional training, cognitive approach, methodology.

Fig.: 5. Lit.: 19.

\section{ИГРОВЫЕ ФОРМЫ НА ЗАНЯТИЯХ ИНОСТРАННОГО ЯЗЫКА КАК СРЕДСТВО ПОВЫШЕНИЯ МОТИВАЦИИ СТУДЕНТОВ К ИЗУЧЕНИЮ ЭКОНОМИЧЕСКОГО ВОКАБУЛЯРИЯ}

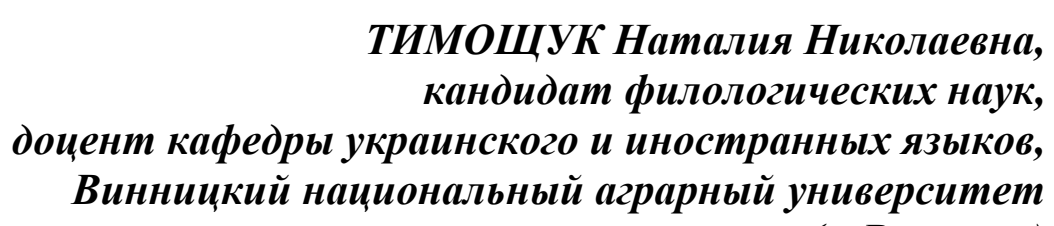

(2. Винница)

В статье исследована проблема повымения мотиващии студентов неязыковых высших учебных заведений к изучению новой научной (экономической) английской лексики путем использования игровых методов на занятиях иностранного языка. Рассмотрена мотивачия студентов учреждения высшего образования при изучении иностранного языка как необходимая составная учебного прочесса. Представлены результаты мониторинга о наличии проблемы усвоения новой профессиональной лексики, оптимальной формы организачии обучения новых терминов и эффективных средств обучения и запоминания вокабулярию среди студентов факультета менеджмента и права Винницкого начионального университета. Осуществлен сравнительный анализ качества и успеваемости студентов до и после использования игровых форм на занятиях по дисциплине "Иностранный язык профессионального направления". Отмечено, что овладение иноязычной профессиональной лексикой - ключевая составляющая в изучении иностранного языка профессионального направления, которая позволяет повысить эффективность учебного процесса, способствует формированию компетентного специалиста, конкурентоспособного в современных условиях. Доказано, что рассматриваемая форма организаџии усвоения экономической профессиональной лексики значительно улучшает способность студентов эффективно запоминать новые англоязычные профессиональные термины, повышая их мотивацию к изучению новой терминологической лексики делового английского языка. 


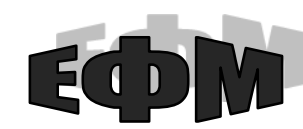

http://efm.vsau.org/

Ключевые слова: мотивация, игровая форма, сроки, вокабулярий, иностранный язык профессионального направления, профессиональная подготовка, когнитивный подход, методика.

Рис.: 5. Лит.: 19.

Постановка проблеми. У контексті сучасних освітніх реформ значна увага приділяється не лише професійній підготовці майбутнього фахівця, а й формуванню особистості, здатної адаптуватися до сучасних умов розвитку українського суспільства, яке нині почало усвідомлювати домінуючу роль мовної освіти. Фахівець, який володіє іноземною мовою, має кращі перспективи при працевлаштуванні, стажуванні за кордоном, участі у міжнародних проектах i конференціях, ознайомленні із зарубіжним досвідом за фахом. На слушну думку Кравця Р.А., в умовах інтеграції нашої держави у загальноєвропейський освітній, економічний i соціокультурний простір практичне оволодіння іноземною мовою також необхідне для реалізації такого аспекту професійної діяльності, як налагодження міжнародних контактів [1, с. 98].

Зазначені вище аспекти, звісно, зумовлюють не лише структуру, цілі, зміст i особливості організації навчально-виховного процесу, а й мотиваційні механізми та необхідні педагогічні умови для забезпечення якісної професійної підготовки майбутнього фахівця, надаючи пошуку ефективної мотивації студентів закладів вищої освіти до вивчення іноземної мови професійного спрямування пріоритетного значення, адже “ефективне використання мотивації дозволяє виявити внутрішні резерви особистості для іiі розвитку, навчання та виховання, оскільки через мотивацію можна впливати як на продуктивність діяльності, так і на розвиток самої особистості" [2, с. 448].

Аналіз останніх досліджень і публікацій. Проблемам підвищення мотивації навчальної діяльності студентів присвячені роботи багатьох науковців: О. Гринчишина [3], Л. Довгань [4], I. Зимньої [5], Г. Китайгородської [6], І. Красноголової [7], О. Малінки [8], О. Яцишина [9].

Питання використання ігор на заняттях з іноземної мови професійного спрямування неодноразово досліджували Р. Кравець [1], І. Лобачук [10], О. Пасічник [11], О. Пометун [12], С. Цимбал [13], науковці акцентують увагу на значному потенціалі інтерактивних методів у вивченні іноземних мов, зокрема наголошують на їх ефективності для засвоєння масивів економічної термінологічної лексики іноземною мовою.

Проте, незважаючи на значний інтерес до різних аспектів підвищення мотивації до вивчення іноземної мови студентами немовних закладів вищої освіти, спостерігається зниження цілеспрямованості освітніх мотивацій студентів.

Формулювання цілей статті. Цією публікацією ми маємо на меті дослідити проблему підвищення мотивації студентів немовних закладів вищої освіти до вивчення нової наукової (економічної) англійської лексики шляхом використання ігрових методів на заняттях з іноземної мови.

Виклад основного матеріалу дослідження. Сучасна педагогічна наука розглядає мотивацію як один з ключових факторів навчання. Р.А. Готліб зазначає, що це така рушійна сила, яка спонукає людину до успішного вивчення іноземної мови $[14$, c. 122]. Петсі Лайтбаун та Ніна Спада, аналізуючи важливість мотивації та іiі вагомість, наголошують, що “основний спосіб впливу викладачів на мотивацію студентів є формування сприятливого навчального середовища, яке стимулюватиме 


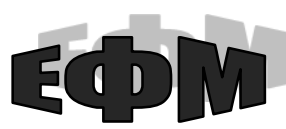

http://efm.vsau.org/

та заохочуватиме водночас" [15, с. 124]. 3 метою забезпечення розвитку творчої мотивації майбутніх фахівців при організації навчання іноземної мови викладачеві потрібно подолати психологічний бар'єр у спілкуванні зі студентами, надати їм психологічної підтримки, перетворити їх на друзів, рівноправних партнерів [16, c. 283-284]. Іншими словами, мотивовані студенти мають кращі шанси успішно опанувати новий навчальний матеріал, зокрема вокабулярій.

Сучасні науковці наголошують на необхідності варіативного використання різних методів навчання задля підвищення ефективності викладання іноземних мов у закладах вищої освіти: “акваріум”, “два - чотири - усі разом”, “мозковий штурм”, “навчаючись - учусь”, “незакінчені речення”, “дерево рішень”, “коло ідей”, “мікрофон”, “ротаційні трійки”, “мозаїка”, “судове слухання”, “громадські слухання”, “займи позицію”, “зміни позицію”, “шкала думок”, імітаційні ігри, рольова гра, дискусія, дебати тощо $[1 ; 12 ; 16 ; 17]$. На нашу думку, вивчення нової лексики незвичним ігровим способом може сприяти засвоєнню значного масиву іншомовних (англійських) термінів. "Усі методи навчання слід добирати 3 урахуванням особистісно-зорієнтованого та діяльнісного підходів, тобто орієнтуватися на активну взаємодію студентів і викладачів, зважаючи на їхні особистісні можливості" [1, с. 100]. Принагідно зазначимо, що обираючи аналізовану форму навчання, викладачеві також потрібно враховувати вік і сферу інтересів студентів.

Опитування, проведене в групах студентів факультету менеджменту та права другого курсу Вінницького національного аграрного університету (всього було опитано близько 50 осіб), дало змогу з'ясувати, по-перше, наявність / відсутність проблеми засвоєння нової фахової лексики; по-друге, оптимальнішу (легшу, на думку респондентів) форму організації навчання нових термінів: читання чи аудіювання; по-третє, найефективніші (на думку респондентів) засоби навчання та запам'ятовування вокабулярію.

Перше питання анкети було сформовано таким чином: “Чи важко Вам запам'ятовувати нову професійну лексику? (Do you find memorizing new terms difficult?)". Результати представлено у формі графіку (рис. 1), з якого видно, що 46 \% респондентів виокремили проблему важкості засвоєння нового лексичного матеріалу.

- Чи важко Вам запам ятовувати нову професійну лексику?; Hi; 54\%

Чи важко Вам запам ятовувати нову професійну лексику?; Так; $46 \%$

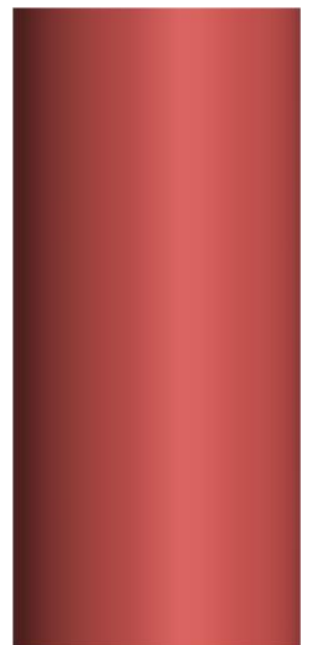

Рис. 1. Наявність проблеми запам'ятовування нового лексичного матеріалу, \% Джерело: власні дослідження автора 


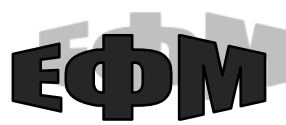

http://efm.vsau.org/

За допомогою другого графіку (рис. 2) показано результати моніторингу форми організації навчання нових термінолексем ділової іноземної мови. Як свідчать дані, $62 \%$ опитаних студентів обрали аудіювання, як складнішу форму сприйняття нового лексичного матеріалу, порівняно з читанням, відповівши на питання: “Яка форма сприйняття нової лексики є для вас більш складною: читання чи аудіювання? (What language skill do you find more difficult learning new vocabulary: a) listening; b) reading?)".

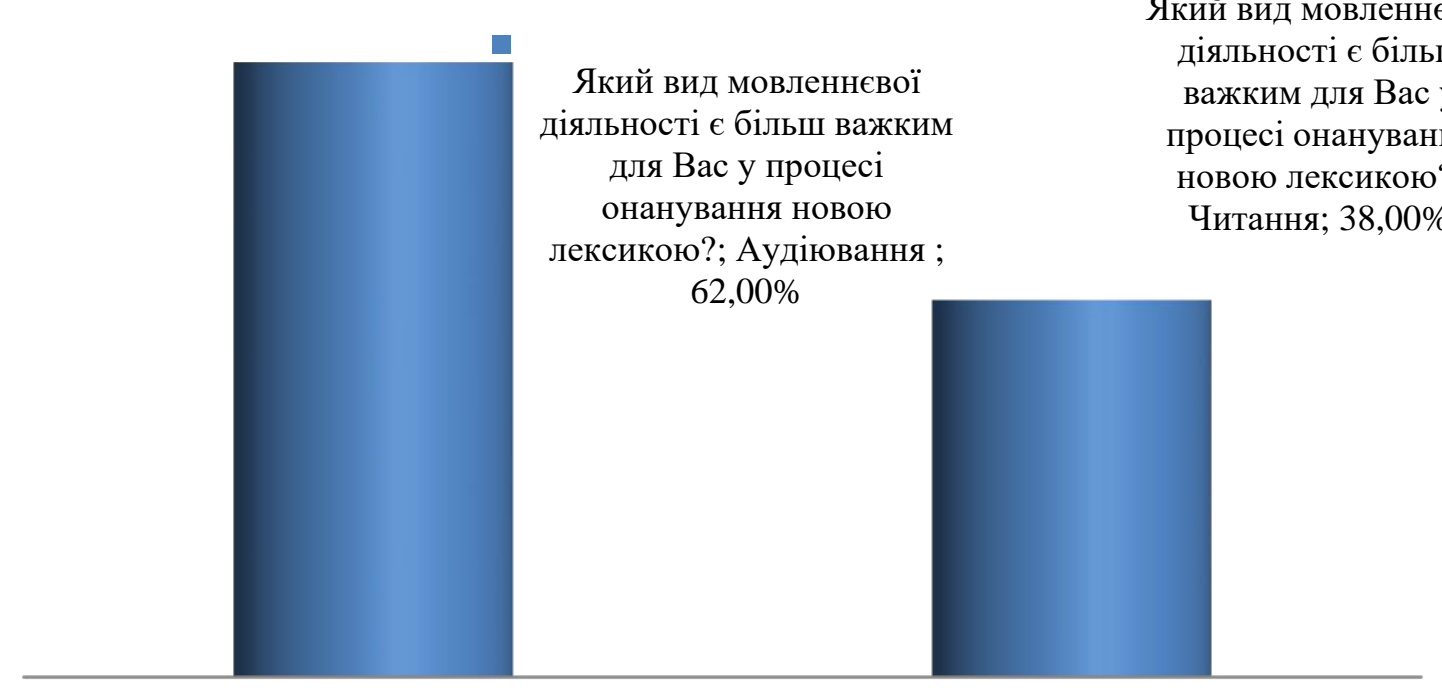

Який вид мовленнєвс діяльності є більш важким для Вас у процесі онанування новою лексикою?; Читання; 38,00\%

Puc. 2. Форма сприйняття нового лексичного матеріалу, \%

Джерело: власні дослідження автора

Основна форма навчання іноземної мови професійного спрямування у вищій школі - практичне заняття. У ході нашого дослідження ми намагалися з'ясувати, яким заняттям з іноземної мови надають перевагу студенти факультету менеджменту та права ВНАУ. За допомогою діаграми (рис. 3) представлено вподобання опитаних студентів щодо пріоритетності формування іншомовних навиків на аудиторних заняттях.

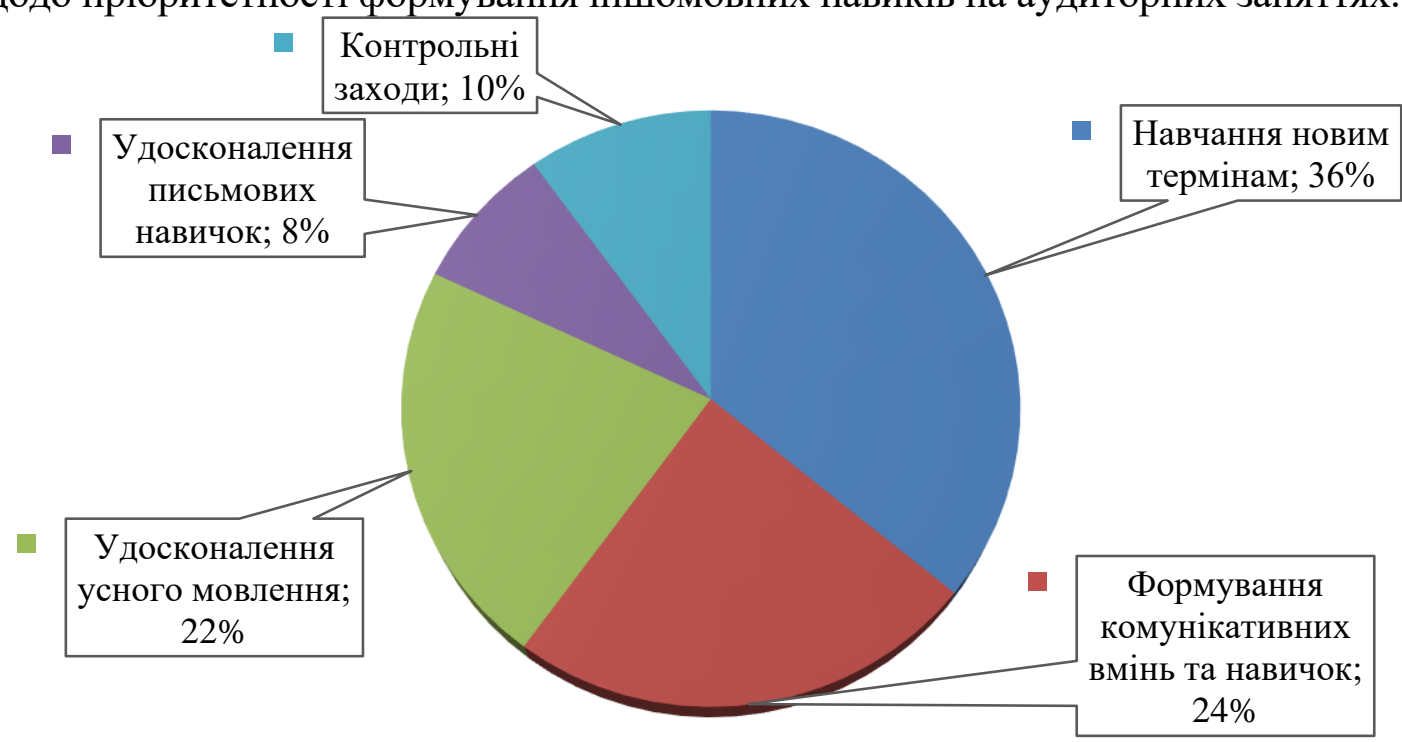

Puc. 3. Пріоритетність формування іншомовних навиків на заняттях 3 іноземної мови, \%

Джерело: власні дослідження автора 


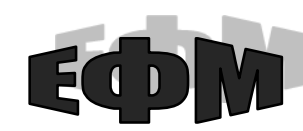

http://efm.vsau.org/

3'ясовано, що 36\% респондентів обрали заняття з засвоєння нових фахових термінів; 24\% студентів віддали пріоритет заняттю 3 формування комунікативних знань, умінь і навичок; питання удосконалення та підвищення якості усного мовлення $є$ преважаючим для $22 \%$ опитаних; написання та оформлення різних письмових висловлювань є головним на занятті для 8 \% майбутніх менеджерів, 10 \% відвідують заняття з метою оцінювання їх рівня володіння всіма видами мовленнєвої діяльності. Виходячи 3 отриманих результатів, переважна більшість студентів факультету менеджменту та права ВНАУ прагнуть на заняттях 3 іноземної мови засвоїти якомога більше нових термінів з обраного фаху, що надає аналізованій проблемі ще більшої вагомості.

Анкетування також дало змогу виявити основні стратегії успішного засвоєння іншомовного вокабулярію, на думку респондентів: використання у різноманітних комунікативних ситуаціях, наведення прикладів, ігрові форми, прослуховування нових термінів, картки, використання зображень (малюнків), з'ясовування лексичного значення та / або перекладу за допомогою довідкової літератури, зокрема словників. Результати аналізу представлено у вигляді діаграми (рис. 4). Варто зазначити, що $20 \%$ опитаних студентів надають перевагу ігровій формі у вивченні нової фахової термінології 3 дисципліни: “Іноземна мова професійного спрямування", тому вважаємо, що аналізована стратегія може використовуватися на практичних заняттях, адже, фактично, іiї обирає кожен п’ятий респондент.

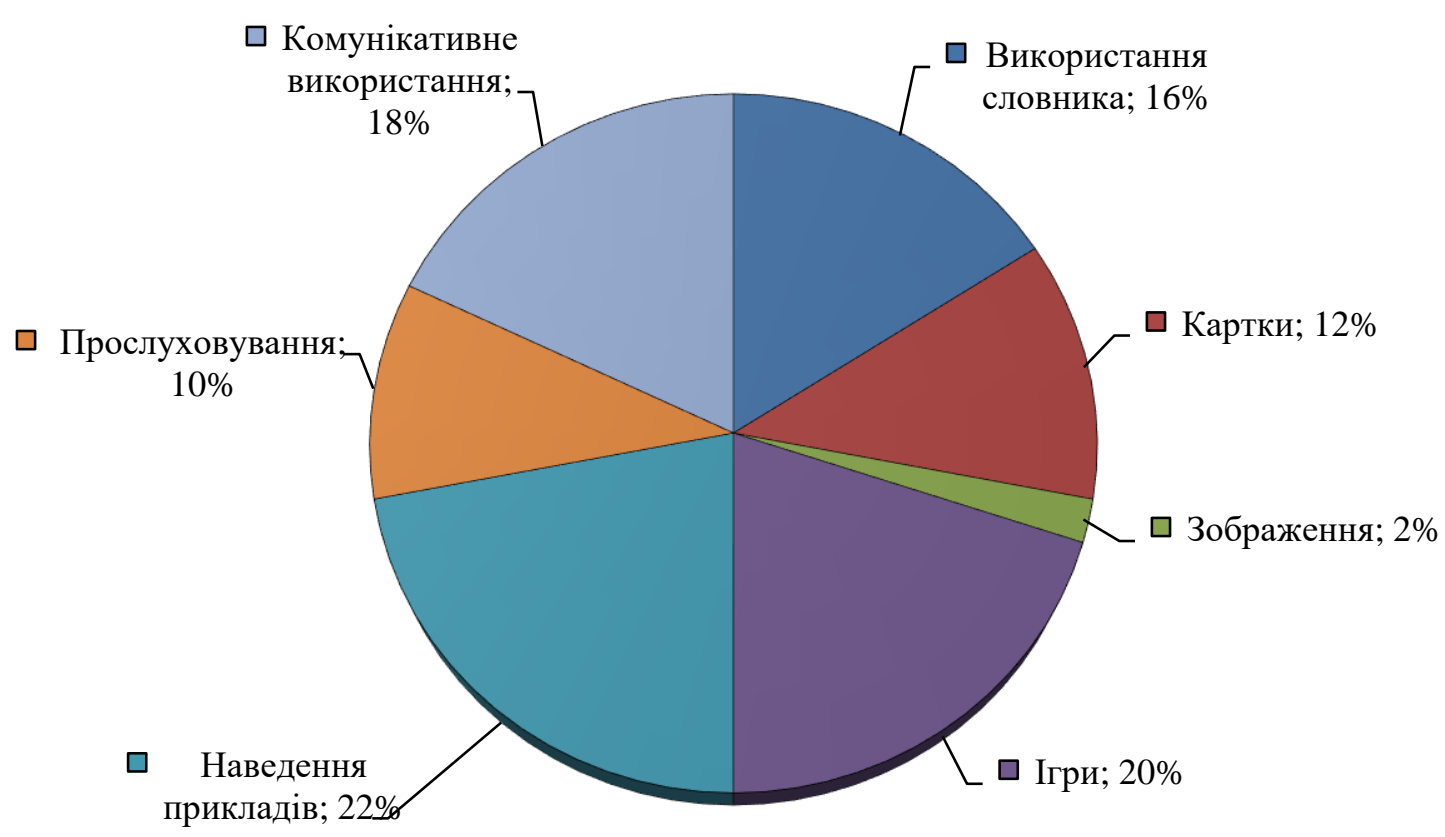

Рис. 4. Стратегії вивчення нової лексики, \%

Джерело: власні дослідження автора

На заняттях з іноземної мови професійного спрямування ми використовували три загальновідомі та загальноприйняті у світовій практиці ігрові форми: "I Have Who Has", Fly Swat Game та головоломки для навчання лексики протягом двох місяців (вісім занять). Діаграма (рис. 5) демонструє навчальні показники студентів до 


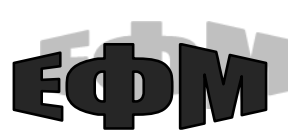

http://efm.vsau.org/

та після використання ігрової форми. Слід зазначити, що до їх застосування якість навчання студентів була 40\%, а успішність - 90\% (2 студентів (4\%) мали відмінні оцінки - “А” за шкалою ЕCTS; 20 студентів (40\%) отримали оцінку “добре”: "В” - 6 студентів (12\%), “C” - 14 студентів (28\%) за шкалою ECTS; 23 студентів (46\%) мали задовільні оцінки: “Д” - 12 студентів (24\%), “Е” - 11 студентів (22\%) за шкалою ECTS; 5 студентів (10\%) отримали незадовільні оцінки - “FX” за шкалою ECTS).

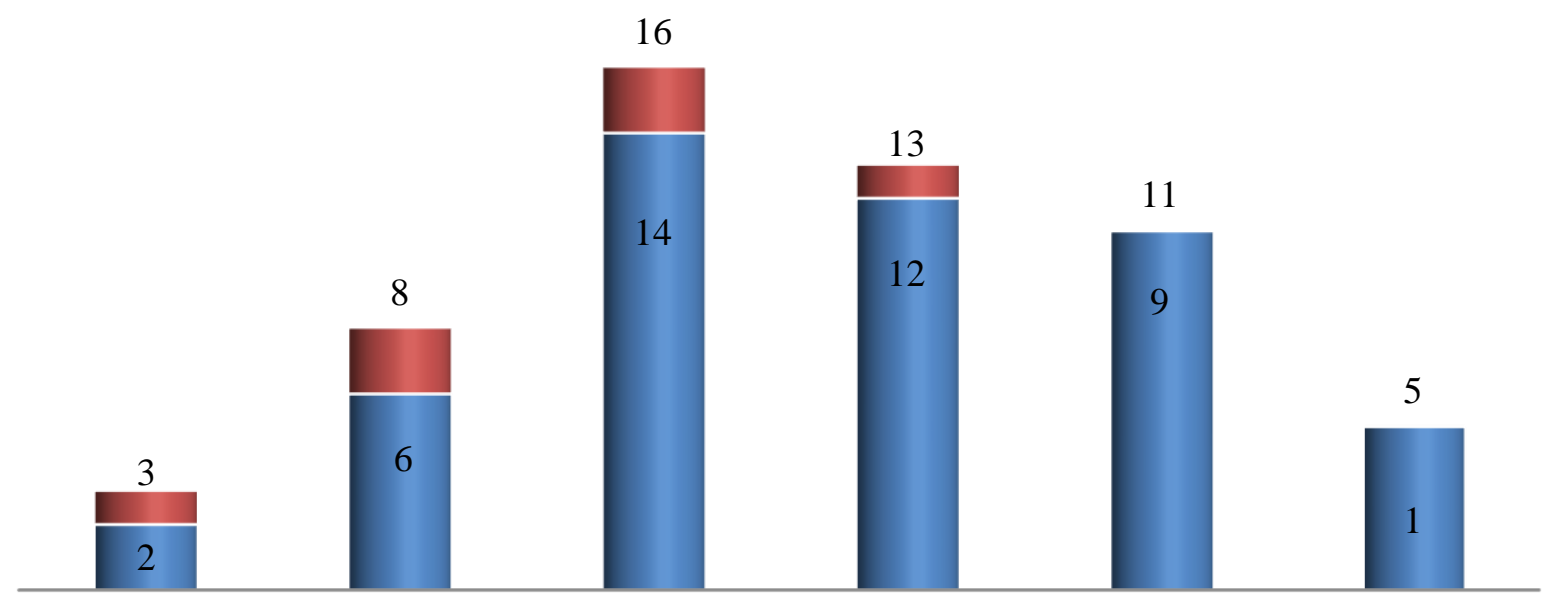

- До експерименту $\quad$ Після експерименту

Рис. 5. Порівняльний аналіз успішності студентів, осіб

Джерело: власні дослідження автора

Дані дослідження засвідчили ефективність використання ігрових методів під час засвоєння нового іншомовного лексичного матеріалу. Таким чином, якість навчання студентів зросла на $16 \%$, а успішність - на $8 \%$, становлячи відповідно $56 \%$ та 98\%. З'ясовано, що 3 студентів (6\%) отримали відмінні оцінки; 24 студенти (48\%) - оцінку "добре": "B" - 8 студентів (16\%), "C" - 16 студентів (32\%) за шкалою ЕСТS; 22 студенти (44\%) - задовільні оцінки: "D" - 13 студентів (26\%), “C" - 9 студентів (18\%) за шкалою ECTS; незадовільну оцінку (“FX") мав лише один студент.

Ми погоджуємося $з$ думкою Р.А. Кравця, що система оцінювання - невід'ємна складова ігрової методики, адже вона має на меті забезпечувати контроль якості засвоєних знань, водночас сприяючи розгортанню ігрової форми навчального процесу. Звісно, така система виконує функцію як контролю, так і самоконтролю $[1$, с. 102]. Зміст ігрової форми визначається, безперечно, ііі навчальними цілями. Однак iï використання не лише значно збільшило словниковий запас студентів, а й спричинило підвищення рівня їх мотивації до вивчення іноземної мови фахового спрямування.

Ми вважаємо, що накопичення та засвоєння масиву економічного вокабулярію значним чином залежить від раціонально, усвідомленого сприйняття реципієнтами (студентами) термінолексем на їх позначення. Зауважимо, що когнітивний підхід, який "активно розвивається у вітчизняній та світовій психології, когнітології, психонометриці, психолінгвістиці та лінгводидактиці, покликаний вирішити непросте завдання, яке полягає не тільки в запам'ятовуванні іншомовних слів i виразів, а й в опануванні понять, явищ, процесів, механізмів, законів та інших 


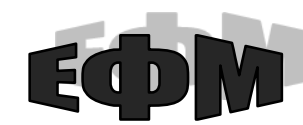

http://efm.vsau.org/

феноменів, які вони позначають” [18, с. 238]. Скот Торнбері зазначав: “Чим більше усвідомлених рішень студенти приймають стосовно слова, і чим вищий $є$ рівень його когнітивного усвідомлення, тим краще це слово запам'ятовується" [19, с. 25]. Таким чином, використання ігрових методів підвищує здатність студентів запам'ятовувати нові слова, оскільки вони активують їх когнітивну діяльність.

Висновки. Використання ігрових форм для вивчення економічного вокабулярію на заняттях 3 іноземної мови професійного спрямування значно покращує здатність студентів ефективно запам'ятовувати нові англомовні фахові терміни. Аналізована стратегія підвищила мотивацію студентів до вивчення нової термінологічної лексики ділової англійської мови, якість їхніх знань та успішність 3 дисципліни "Іноземна мова професійного спрямування".

Дослідження потенціалу лексичних ігор як одного з інтерактивних методів навчання та засобу підвищення мотивації студентів до вивчення економічного вокабулярію на заняттях іноземної мови довело, що студенти можуть досить швидко та ефективно засвоювати новий лексичний матеріал 3 подальшим його використанням у професійному спілкуванні. Оволодіння іншомовною фаховою лексикою - ключова складова у вивченні іноземної мови професійного спрямування, яка дає змогу підвищити ефективність навчального процесу, сприяє формуванню компетентного спеціаліста, конкурентоспроможного у сучасних умовах. Отже, використання ігор для вивчення економічної лексики підвищує не лише здатність студентів запам'ятовувати нові терміни, а їх мотивацію до навчальної діяльності.

Ця публікація не вичерпує багатогранності досліджуваної проблеми, тому подальші наукові розвідки вважаємо перспективними, маючи на меті ретельно проаналізувати когнітивний підхід у навчанні студентів економічної англійської термінології.

\section{Список використаних джерел}

1. Кравець Р. А. Ділові імітаційно-рольові ігри на заняттях іноземної мови в професійній підготовці майбутніх економістів. Економіка. Фінанси. Менеджмент: актуальні питання науки і практики: Всеукраӥнський науково-виробничий журнал. 2008. № 6 (34). С. 97-108.

2. Рідель Т.М. Шляхи підвищення мотивації при вивченні англійської мови студентами СНАУ. Молодий вчений. 2017. № 12. С. 448-453.

3. Гринчишин О.М. Розвиток мотивації оволодіння іноземною мовою в умовах вищого військового навчального закладу: дис. ... канд. психол. наук: 19.00.09 / Національна академія державної прикордонної служби України імені Богдана Хмельницького. Хмельницький, 2003. 207 с.

4. Довгань Л.І. Формування мотивації вивчення іноземної мови студентів немовного вищого навчального закладу. Наукові записки Вінницького державного педагогічного університету імені Михайла Коцююинського. Серія: Педагогіка $i$ психологія. 2009. Вип. 26. С. 95-98.

5. Зимняя И. А. Психология оптимизации обучения иностранному языку в школе. Иностранные языки в школе. 1986. № 4. С. 3-7.

6. Китайгородская Г. А. Методика интенсивного обучения иностранным языкам: учеб. пособие. М.: Высш. шк., 1986. 103 с.

7. Красноголова I. Б. Формування мотивів учіння студентів у процесі викладання англійської мови: дис. ... канд. пед. наук: 13.00 .01 / Вінницький державний педагогічний університет імені М. Коцюбинського. Вінниця, 1998. 152 с. 


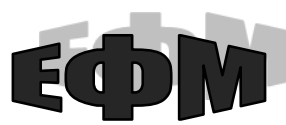

http://efm.vsau.org/

8. Малінка О.О. Особливості формування мотивації до вивчення іноземних мов студентами нелінгвістичних освітніх закладів. Наукові записки Вінницького державного педагогічного університету імені Михайла Кочюбинського. Серія: Педагогіка і психологія. 2009. Вип. 26. С. 115-118.

9. Яцишин О.М. Визначення оптимальної структури мотиваційного синдрому вивчення англійської мови студентами економічних спеціальностей. Мова. Культура. Бізнес. 2003. Вип. 1. С. 308-316.

10. Лобачук I.М. Ділова гра як ефективний засіб навчання студентів нелінгвістичних ВНЗ іноземної мови. Наукові записки Національного педагогічного університету ім. М. П. Драгоманова. Серія: Педагогічні та історичні науки. 2014. Вип. 118. С. 149-155.

11. Пасічник О.О. Особливості використання ділових ігор на заняттях 3 іноземної мови у ВНЗ. Науковий вісник Ужгородського національного університету. Серія: Педагогіка. Соиіальна робота. 2014. Вип. 30. С. 125-127.

12. Пометун О.І., Побірченко Н.С., Коберник Г.І. Інтерактивні технології: теорія та методика. К.: АПН, 2008. 94 с.

13. Цимбал С.В. Застосування активних методів навчання у процесі вивчення англійської мови студентів технічних спеціальностей. Актуальні проблеми педагогіки, психологї̈ та професійної освіти. 2015. № 2. Т.1. С. 43-49

14. Готлиб Р.А. Социальная востребованность. Знание иностранного языка. Соииологические исследования. 2009. № 2. С. 122-127.

15. Lightbown P., Spada N. How Languages are Learned. Oxford: Oxford University Press, 1993. 135 pp.

16. Система довузівської підготовки в країнах Західної Свропи та інноваційні методи навчання у ВНЗ України: Колективна монографія / Калетнік Г.М. та ін. Вінниця, 2013. 469 с.

17. Tymoshchuk N. Professionally-oriented Teaching of a Foreign Language at the Agrarian University. Молодь і ринок. 2019. № 1(168). С. 66-70.

18. Науменко Л., Олійник О. Когнітивний підхід у навчанні студентів англійської термінолексики предметної галузі “мікроекономіка". Психолінгвістика (Філологія). 2018. Вип. 24. Т. 2. С. 236-253.

19. Thornbury S. How to Teach Vocabulary. Longman, 2002. 185 p.

\section{References}

1. Kravets, R.A. (2008). Dilovi imitatsiino-rolyovi ihry na zaniattiakh inozemnoi movy v profesiinii pidhotovtsi maibutnikh ekonomistiv [Business imitation-role games at foreign language classes in the professional training of future economists]. Ekonomika. Finansy. Menedzhment: aktualni pytannia nauky $i$ praktyky - Economy, finances, management: topical issues of science and practical activity, 6 (34), 97-108 [in Ukrainian].

2. Ridel, T.M. (2017). Shliakhy pidvyshchennia motyvatsii pry vyvchenni anhliiskoi movy studentamy SNAU [Ways to improve students' motivation while mastering the English language at SNAU]. Molodyi vchenyi - Young Scientist, 12, 448-453 [in Ukrainian].

3. Hrynchyshyn, O.M. (2003). Rozvytok motyvatsii ovolodinnia inozemnoiu movoiu $\mathrm{v}$ umovakh vyshchoho viiskovoho navchalnoho zakladu [Development of motivation for mastering a foreign language in the conditions of a higher military educational institution]. Candidate's thesis. Khmelnytskyi: National Academy of the State Border Guard Service of Ukraine named after Bogdan Khmelnitsky [in Ukrainian]. 


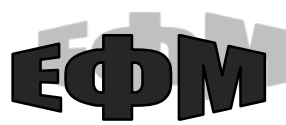

http://efm.vsau.org/

4. Dovhan, L.I. (2009). Formuvannia motyvatsii vyvchennia inozemnoi movy studentiv nemovnoho vyshchoho navchalnoho zakladu [Formation of the motivation to study the foreign language of students of a non-linguistic higher educational institution]. Naukovi zapysky Vinnytskoho derzhavnoho pedahohichnoho universytetu imeni Mykhaila Kotsiubynskoho. Seriia: Pedahohika i psykholohiia - Scientific notes of Vinnytsia State Pedagogical University named after Mykhailo Kotsiubynskyi. Series: Pedagogy and Psychology, 26, 95-98 [in Ukrainian].

5. Zimnyaya, I. A. (1986). Psihologiya optimizatsii obucheniya inostrannomu yazyiku $\mathrm{v}$ shkole [Psychology of optimizing learning a foreign language at school]. Inostrannyie yazyiki v shkole - Foreign languages at school, 4, 3-7. [in Russian].

6. Kitaygorodskaya, G.A. (1998). Metodika intensivnogo obucheniya inostrannyim yazyikam [Methodology of intensive foreign languages studying]. M.: Vyissh. shk. [in Russian].

7. Krasnoholova, I.B. (1998). Formuvannia motyviv uchinnia studentiv u protsesi vykladannia anhliiskoi movy [Formation of students' motivation while teaching English]. Candidate's thesis. Vinnytsia: Vinnytsia State Pedagogical University named after Mykhailo Kotsiubynskyi [in Ukrainian].

8. Malinka, O.O. (2009). Osoblyvosti formuvannia motyvatsii do vyvchennia inozemnykh mov studentamy nelinhvistychnykh osvitnikh zakladiv [Features of the formation of the motivation to study foreign languages by students of non-linguistic educational institutions]. Naukovi zapysky Vinnytskoho derzhavnoho pedahohichnoho universytetu imeni Mykhaila Kotsiubynskoho. Seriia: Pedahohika i psykholohiia Scientific notes of Vinnytsia State Pedagogical University named after Mykhailo Kotsiubynskyi. Series: Pedagogy and Psychology, 26, 115-118 [in Ukrainian].

9. Yatsyshyn, O.M. (2003). Vyznachennia optymalnoi struktyry motyvatsiinoho syndromu vyvchennia anhliiskoi movy studentamy ekonomichnykh spetsialnostei [The optimal structure of the motivation syndrome to study English language by the students of economic spatialities]. Mova. Kultura. Biznes - Language. Culture. Business, 1, 308-316 [in Ukrainian].

10. Lobachuk, I.M. (2014). Dilova hra yak efektyvnyi zasib navchannia studentiv nelinhvistychnykh VNZ inozemnoi movy [Business game as an effective means of foreign language teaching students of non-linguistic higher educational institutions]. Naukovi zapysky Natsionalnoho pedahohichnoho universytetu im. M. P. Drahomanova. Seriia: Pedahohichni ta istorychni nauky - Scientific notes of the National Pedagogical University named after M.P. Drahomanov. Series: Pedagogy and History, 118, 149-155 [in Ukrainian].

11. Pasichnyk, O.O. (2014). Osoblyvosti vykorystannia dilovykh ihor na zaniattiakh z inozemnoii movy u VNZ [Peculiarities of using business games at foreign language classes at higher educational institutions]. Naukovyi visnyk Uzhhorodskoho natsionalnoho universytetu Scientific Bulletin of Uzhgorod National University, 30, 125-127 [in Ukrainian].

12. Pometun, O.I., Pobirchenko, N.S. \& Kobernyk, H.I. (2008). Interaktyvni tekhnolohii: teoriia ta metodyka [Interactive technologies: theory and methodology]. Kyiv: APN [in Ukrainian].

13. Tsymbal, S.V. (2015). Zastosuvannia aktyvnykh metodiv navchannia u protsesi vyvchennia anhliiskoi movy studentiv tekhnichnykh spetsialnostei [Application of active teaching methods while studying English language by students of technical specialties]. Aktualni problemy pedahohiky, psykholohii ta profesiinoi osvity - Urgent issues of pedagogy, psychology and vocational education, Vol. 1, 2, 43-49 [in Ukrainian]. 
14. Gotlib, R.A. (2009). Sotsialnaya vostrebovannost. Znanie inostrannogo yazyika. [Social demand. Knowledge of foreign language]. Sotsiologicheskie issledovaniya Sociological research, 2, 122-127 [in Russian].

15. Lightbown P. \& Spada N. (1993). How Languages are Learned. Oxford: Oxford University Press, 1993 [in English].

16. Kaletnik, H.M., Kravets, R.A., $\quad$ Lazorenko, N.L., Tymkova, V.A. \& Shapovaliuk, L.O. (2013). Systema dovuzivskoi pidhotovky v krainakh Zakhidnoi Yevropy ta innovatsiini metody navchannia u VNZ Ukrainy [The pre-university training system in Western Europe and innovative teaching methods of higher education institutions in Ukraine]. Vinnytsia: VNAU [in Ukrainian].

17. Tymoshchuk N.M. (2019). Professionally-oriented Teaching of a Foreign Language at the Agrarian University. Molod i rynok - Youth \& Market, 1(168), 66-70 [in English].

18. Naumenko, L., Oliinyk, O. (2018). Kohnityvnyi pidkhid u navchanni studentiv anhliiskoi terminoleksyky predmetnoi haluzi "mikroekonomika" [The cognitive approach to teaching students English terminological lexis of the subject field of "Microeconomics"]. Psykholinhvistyka (Filolohiia) - Psycholinguistics (Philology), Vol. 24, Issue 2, 236-253 [in Ukrainian].

19. Thornbury, S. (2002). How to Teach Vocabulary. Longman [in English].

\section{Відомості про автора}

ТИМОЩУК Наталія Миколаївна - кандидат філологічних наук, доцент кафедри української та іноземних мов, Вінницький національний аграрний університет (21008, м. Вінниця, вул. Сонячна, 3, e-mail: redish_fox15@ukr.net).

TYMOSHCHUK Nataliia - Candidate of Philological Sciences, Associate Professor of the Ukrainian and Foreign Languages Department, Vinnytsia National Agrarian University (21008, Vinnytsia, 3 Soniachna Str., e-mail: redish_fox15@ukr.net).

ТИМОЩУК Наталия Николаевна - кандидат филологических наук, доцент кафедры украинского и иностранных языков, Винницкий национальный аграрный университет (21008, г. Винница, ул. Солнечная, 3, e-mail: redish_fox15@ukr.net).

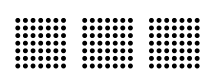

